\title{
All about COVID-19 what do we know?
}

\author{
Dipendra Kadel \\ MBBS Intern, Gandaki Medical College Teaching Hospital and Research Center, Pokhara, Nepal \\ E mail: dipendrakandel5000@gmail.com

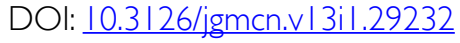

\section{INTRODUCTION}

In December $31^{\text {st }} 2019$, China alerted WHO several flu like cases. As we know the flu has been occurring since decades but the cases were exceptional at those times. January $5^{\text {th }} 2020$ WHO put travel restrictions so that the flu would not transfer from one country to another. Amid the fear lockdown was made. In January $1^{\text {st }} 2020$ first death was reported form the same flu that had started in December 2019. On January $7^{\text {th }}$ the virus was identified as novel-corona virus. The number morbidity and mortality was increasing day by day. In January $31^{\text {st }}$ it was public health emergency of international concern. Seeing the epidemic and possible pandemic WHO strategic preparedness and response plan was released in February $3^{\text {rd }}$. And on February $4^{\text {th }}$ there was request activation of UN crisis management policy to establish a crisis management team. On February $6^{\text {th }}$ WHO briefed on strategic preparedness and response plan. On February $11^{\text {th }}$ the new name was given COVID-19. And on February $12^{\text {th }}$ strategic preparedness and response plan operational planning guide was released.

The main aim of the plan was to support the UN country team in providing guidance to national governments and partners in scaling up response to COVID-19. And three core response strategies are to rapidly establish international coordinates and operational support. Scaling up country readiness and response operation and accelerating priority research and innovation.

\section{ABOUT THE DISEASE COVID-19}

It is an acute viral illness caused by severe acute respiratory syndrome CoV-2(SARS-CoV-2). It is related to group of coronaviruses that cause disease in mammals and birds. Similar to the recent pandemic there was severe acute respiratory syndrome (SARS) in 2003 and Middle east respiratory syndrome (MERS) in 2012. They are enveloped viruses with a positive-sense singlestranded RNA genome. The name coronavirus is derived from the Latin corona, meaning crown, which refers to the characteristic appearance reminiscent of a solar corona around the virions.

\section{TRANSMISSION OF THE VIRUS}

It is transmitted by droplet infection by sneezing, coughing and contamination of fomites and surface articles. It infects human cells by attaching to the angiotensin-converting enzyme 2 (ACE2) receptor. The incubation period of the virus ranges from two to fourteen days and main risks to the viruses are health care personnel, $60+$ age groups, immunocompromised patients, children and those with malignancy. The symptoms can range from mild viral prodrome like dry cough, fever, malaise to severe lethal consequences like pneumonia, kidney failure and death.

\section{DIAGNOSIS}

The diagnosis is done by two methods RT-PCR and detection of the antibodies in the serum. In clinical settings RT-PCR is best method and antibodies detection should be limited to surveillance. No any cure is made till now nor vaccine is made and the treatment is symptomatic.

\section{PREVENTION OF THE DISEASE}

- Cover mouth and nose while sneezing and coughing

- Avoid close contacts

- Use PPE while in health care facility

- Cook the foods thoroughly

- Stay at home during epidemic

- Seek early medical advice amid symptoms

\section{EIGHT PILLARS TO STOP OUTBREAK, EPIDEMIC AND PANDEMIC}

The eight pillars to stop any possible outbreak, epidemic and pandemic are given as below: 


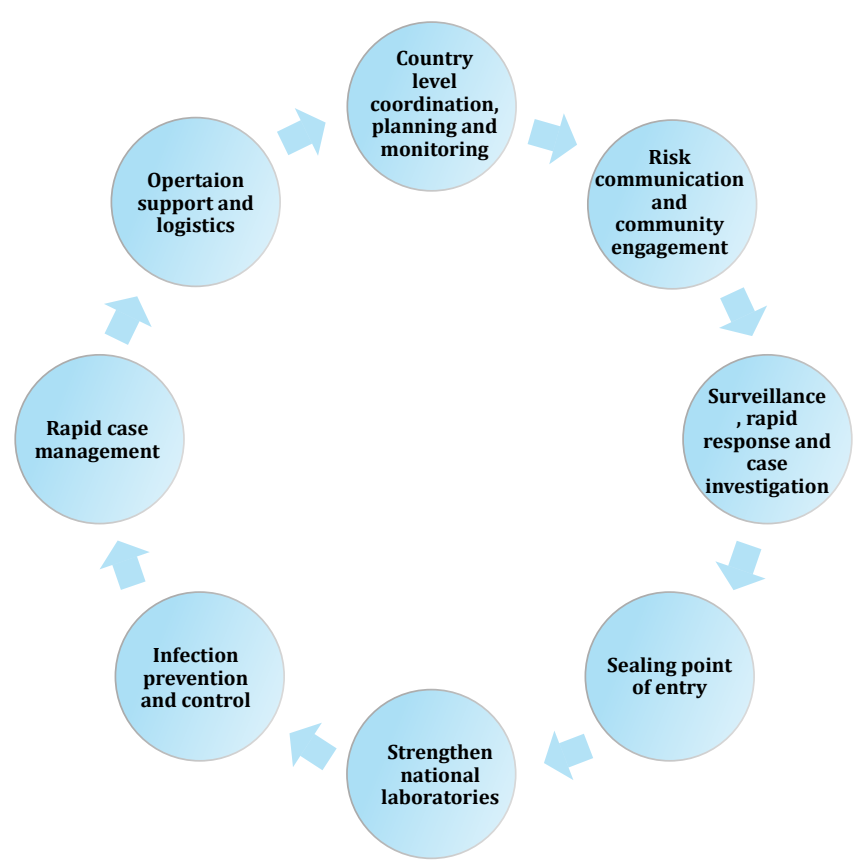

\section{THE PROTOCOL FOR THE INVESTIGATION OF THE CASES ACCORDING TO WHO}

\begin{tabular}{|c|c|}
\hline $\begin{array}{c}\text { Objectives of the inves- } \\
\text { tigation }\end{array}$ & $\begin{array}{l}\text { The objectives of any investigation of a suspected } \\
\text { COVID-19 case include: } \\
\text { - Rapidly detect COVID-19 and any evidence of } \\
\text { human-to-human transmission among contacts } \\
\text { - Reduce human-to-human transmission, prevent } \\
\text { outbreaks, and delay the spread of disease }\end{array}$ \\
\hline $\begin{array}{c}\text { Composition, } \\
\text { protection } \\
\text { of and tools for the } \\
\text { investigative team }\end{array}$ & $\begin{array}{l}\text { Composition } \\
\text { Personnel with the capacity, knowledge, and } \\
\text { authority to: } \\
\text { - Interview persons with suspected COVID-19 and } \\
\text { conduct contact tracing } \\
\text { - Triage suspected COVID-19 cases and contacts } \\
\text { for health care depending on clinical condition } \\
\text { - Collect respiratory specimens from suspected } \\
\text { COVID-19 cases } \\
\text { - Recommend and implement measures to prevent } \\
\text { further transmission } \\
\text { Protection } \\
\text { The COVID-19 virus is spread through contact, } \\
\text { droplet, and fomites. To minimize risk of infection } \\
\text { of the investigation team: } \\
\text { - Optimize size of team to minimize contact with a } \\
\text { suspected CoVID-19 case } \\
\text { Ensure all those in the investigation team are } \\
\text { trained in IPC measures specific to COVID-191 } \\
\text { - Interview suspected cases and contacts over the } \\
\text { phone, if feasible, or at a distance of more than } \\
\text { One metre. } \\
\text { Tools } \\
\text { - Provide sufficient and appropriate PPE2 } \\
\text { - Gather biological specimen collection material, } \\
\text { transport containers, viral transport media, } \\
\text { labels, bags, coolers, and cold packs } \\
\text { touestionnaires, contact tracing and monitoring } \\
\text { tools, and the national case definition }\end{array}$ \\
\hline
\end{tabular}

\begin{tabular}{|c|c|}
\hline $\begin{array}{c}\text { Investigation case } \\
\text { definition }\end{array}$ & $\begin{array}{l}\text { - Adjust national/WHO case definitions } 3 \text { for the } \\
\text { purpose of investigation (define time, person, } \\
\text { place) for additional case finding and contact } \\
\text { tracing (Figure) }\end{array}$ \\
\hline Contact Tracing & $\begin{array}{l}\text { Identify all social, familial, work, and health care } \\
\text { worker contacts who have had contact8 with a } \\
\text { confirmed case from two days before symptom } \\
\text { onset of the case and up to fourteen days after } \\
\text { their symptom onset. Create a line list, including } \\
\text { demographic information, date of first and last } \\
\text { common exposure or date of contact with the } \\
\text { confirmed or probable case, and date of onset if } \\
\text { fever or respiratory symptoms develop. The common } \\
\text { exposures and type of contact with the confirmed or } \\
\text { probable case should be thoroughly documented for } \\
\text { any contacts that become infected with CoviD-19. } \\
\text { Instructions can be found } \\
\text { WWW.WHO.COM }\end{array}$ \\
\hline $\begin{array}{l}\text { Management of case(s) } \\
\text { and contacts }\end{array}$ & $\begin{array}{l}\text { COVID-19 case(s) } \\
\text { - All patients with suspected COVID-19 who have } \\
\text { severe acute respiratory infection should be } \\
\text { triaged and isolated at the first point of contact } \\
\text { with the health care system. Emergency treatment } \\
\text { should be started based on disease severity. } \\
\text { - For those presenting with mild illness, } \\
\text { hospitalization may not be required unless there } \\
\text { is concern about rapid deterioration. If there is } \\
\text { only mild illness, providing care at home may } \\
\text { be considered, with strict precautions regarding } \\
\text { when to seek care. } \\
\text { Contacts } \\
\text { For contacts of a suspected CovID-19 case, at a } \\
\text { minimum, health authorities need to encourage } \\
\text { respiratory and hand hygiene and may encourage, } \\
\text { depending on the epidemiological context } \\
\text { and resources available, self-monitoring for } \\
\text { symptoms, social distancing, or quarantine. } \\
\text { For contacts of a laboratory-confirmed CoviD-19 } \\
\text { case, WHO recommends that such persons be } \\
\text { quarantined for } 14 \text { days from the last time they } \\
\text { were exposed to a CoviD-19 patient.6 }\end{array}$ \\
\hline
\end{tabular}

From all confirmed cases and their contacts, a respiratory sample should be collected and tested as soon as possible, particularly contacts with symptoms. ${ }^{7}$ Respiratory samples from quarantined persons, irrespective of whether they have symptoms, should be sent for laboratory testing at the end of the quarantine period.

Collection and testing of specimens
Ensure that all those involved in collection and transportation of specimens should be trained in safe handling practices and spill decontamination procedures. ${ }^{6}$

For laboratory-confirmed cases, two negative specimens at least one day apart indicate recovery from infection. Based on initial data, this is estimated to be 14 days after the end of illness for mild cases of infection. 


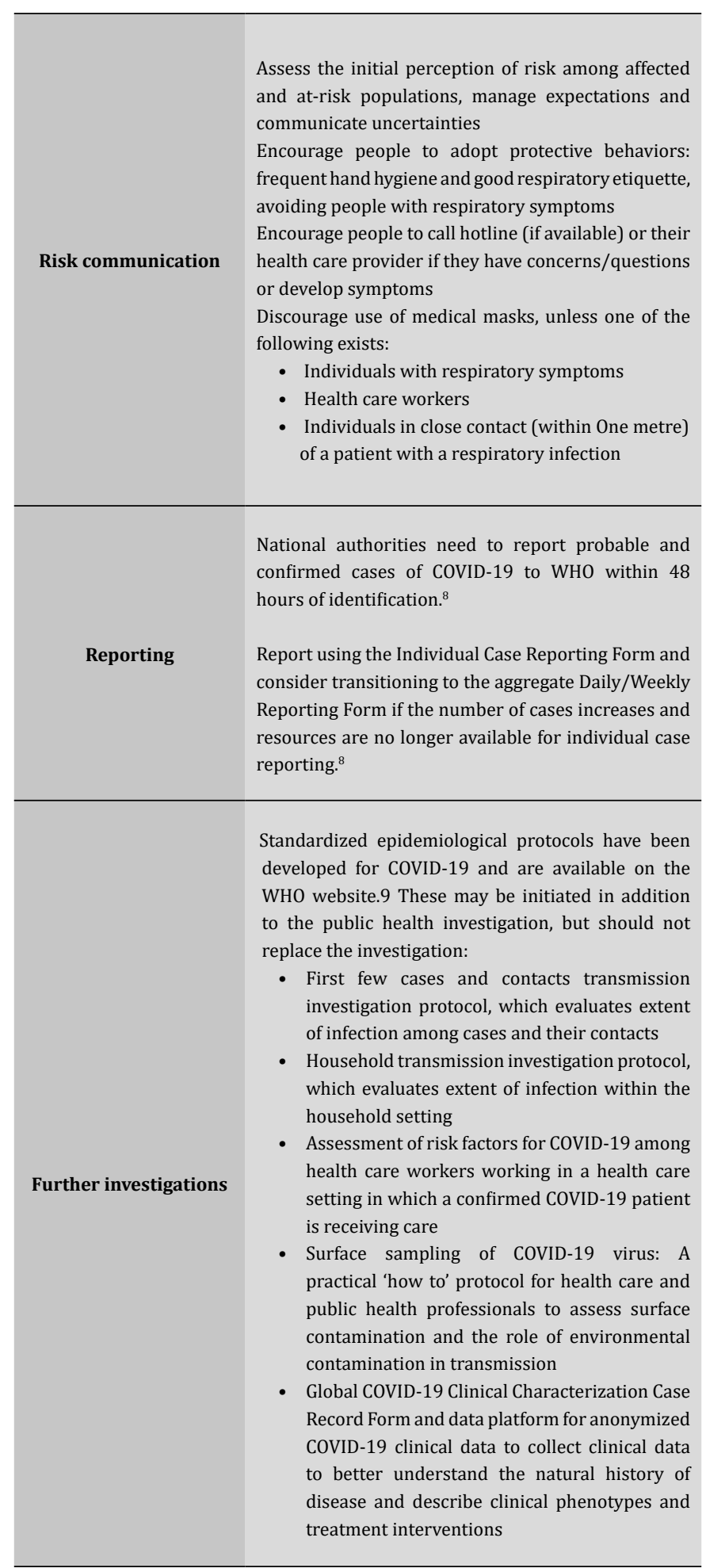

\section{CONTACT TRACING:}

In the community: Once the case is identified we have to identify contacts and monitor them for 14 days. If no symptoms develop monitoring can stop. If symptoms appear then isolate, test and treat for COVID-19. The monitoring can only be stopped if two consecutive tests are negative.
In Hospital: If there is case in hospital is identified then we have to identify contacts and monitor them for 14 days. We should test all the health care workers and patients contacts regardless of the appearance of symptom. If positive then isolate the patient until two consecutive negative tests. And while monitoring if the symptoms develop then we should isolate the case until two consecutive negative tests.

\section{REFRENCES:}

1 World Health Organization. Infection prevention and control. Considerations in the investigation of cases and clusters of COVID-19 Interim guidance 13 March 2020. Available from https://www.who.int/ emergencies/diseases/novel-coronavirus-2019/ technical-guidance/infection-prevention-andcontrol . [Accessed April 3 2020]

2 World Health Organization. Infection prevention and control. Considerations in the investigation of cases and clusters of COVID-19 Interim guidance 13 March 2020. Available from https://www.who. int/publications/i/item/infection-prevention-andcontrol-during-health-care-when-novel-coronavirus(ncov)-infection-is-suspected-\%2020200125. [Accessed April 3 2020]

3 World Health Organization. Infection prevention and control. Considerations in the investigation of cases and clusters of COVID-19 Interim guidance 13 March 2020.Available from https://www.who.int/ publications/i/item/global-surveillance-for-humaninfection-with-novel-coronavirus-(2019-ncov). [Accessed April 4]

4 World Health Organization. Infection prevention and control. Considerations in the investigation of cases and clusters of COVID-19 Interim guidance 13 March 2020. Available from https://www.who. int/publications/i/item/clinical-management-ofsevere-acute-respiratory-infection-when-novelcoronavirus-(ncov)-infection-is-suspected. [Accessed April 4 2020]

5 World Health Organization. Infection prevention and control. Considerations in the investigation of cases and clusters of COVID-19 Interim guidance 13 March 2020..Available from https://www.who. int/publications/i/item/home-care-for-patientswith-suspected-novel-coronavirus-(ncov)-infectionpresenting-with-mild-symptoms-and-managementof-contacts. [Accessed April 4 2020] 
6 World Health Organization. Infection prevention and control. Considerations in the investigation of cases and clusters of COVID-19 Interim guidance 13 March 2020. Available from https://www.who.int/publications/i/ item/considerations-for-quarantine-of-individuals-inthe-context-of-containment-for-coronavirus-disease(covid-19). [Accessed April 4 2020]

7 World Health Organization. Infection prevention and control. Considerations in the investigation of cases and clusters of COVID-19 Interim guidance 13 March 2020. Available from https://www.who.int/publications/i/ item/laboratory-testing-for-2019-novel-coronavirusin-suspected-human-cases-20200117. [Accessed April 4 2020]

8 World Health Organization. Infection prevention and control. Considerations in the investigation of cases and clusters of COVID-19 Interim guidance 13 March 2020. Available from https://www.who.int/publications/i/ item/global-surveillance-for-human-infection-withnovel-coronavirus-(2019-ncov). [Accessed April 5 2020]

9 World Health Organization. Infection prevention and control. Considerations in the investigation of cases and clusters of COVID-19 Interim guidance 13 March 2020. Available from https://www.who.int/emergencies/ diseases/novel-coronavirus-2019/technical-guidance/ early-investigations. [Accessed April 5 2020] 